\title{
Capital Ownership and the Political Economy of Free Trade Agreements
}

\author{
Derek Pyne \\ University of Waterloo
}

\begin{abstract}
This article examines the political economy of free trade agreements. It assumes that, unlike labour, capital in two countries is owned and represented by the same lobby group. Using a Heckscher-Ohlin framework, factors affecting the likelihood of political parties and lobby groups supporting free trade agreements are investigated. The effects of free trade agreements on tariffs facing non-member countries are also examined.
\end{abstract}

- JEL classification: F1, D7

- Keywords: Trade agreements, Endogenous trade policy

\section{Introduction}

This article contributes to the expansion of the endogenous trade policy literature to the formation of free trade agreements. Until relatively recently, much of the literature assumed that a country took its terms of trade and the trade policy of the rest of the world as given when forming its own trade policy. Recently, more attention has focused on trade agreements and customs unions. ${ }^{1}$ This paper assumes that at least two countries in the world can influence the trade policy of each other by being willing to enter into a bilateral free trade agreement.

Unlike most of the existing literature, this article assumes that capital in both countries is jointly owned (through either multinational corporations or a stock

\footnotetext{
*Corresponding address: Derek Pyne, Department of Economics, University of Waterloo, 200 University Avenue West, Waterloo, Ontario, Canada, N2L 3G1, E-mail: dpyne@artsmail.uwaterloo.ca, Phone: 519-888-4567 x 35211, Fax: 519-725-0530
} 
market), and represented by the same lobby group. Using a Heckscher-Ohlin framework, this article examines the effect of joint ownership of capital on the formation of free trade agreements and the level of tariffs with other countries.

Nations that enter into free trade agreements often have significant interests in each other's capital stock. Consider the American and Canadian partnership in the North American Free Trade Agreement. In 2006, the \$273.7 billion (Canadian dollars) in direct foreign investment the United States held in Canada, represented 61 percent of all direct foreign investment in Canada (Statistics Canada, 2007). The $\$ 223.6$ billion Canada held in direct foreign investments in the United States, represented 43 percent of Canadian direct foreign investments abroad. Another example is the Closer Economic Relations agreement between Australia and New Zealand. As of March 31, 2007, Australia accounted for 31.1 percent of total foreign investments in New Zealand (Statistics New Zealand, 2007). Moreover, 27.1 percent of total New Zealand investments abroad were in Australia. In the case of European Union countries, well over 60 percent of direct foreign investment was from other European Union countries (Eurostat, 2007). Given the importance of such cross-country ownership of capital among free trade partners, it is important to study its possible political implications.

Section 2 presents the basic model. The model involves three countries with different capital-labour ratios. A free trade agreement is an option for the two most capital abundant countries. Trade policy in each of these countries is determined by the outcome of an election contested by two political parties. Using campaign contributions, country specific labour lobbies and a joint capital lobby influence the political party platforms and the outcomes of the elections. To avoid the complication of terms of trade effects, each country is assumed to be small relative to the rest of the world.

Section 3 investigates the implications of the basic model. Two of the more important implications involve the effect free trade agreements between the two countries have on tariffs facing the rest of the world. It finds that under certain conditions, one member's tariff with the rest of the world increases because of a

\footnotetext{
${ }^{1}$ Examples that deal with the political economy of trade agreements include Ornelas (2005), Kim (2000), Levy (1997), Panagariya and Findlay (1996), Milner and Rosendorff (1996), Grossman and Helpman (1995), Richardson (1994, 1993), Feenstra and Lewis (1991).

${ }^{2}$ These results differ from those of Richardson (1993) who, using a political support function framework, finds that external tariffs will fall. Using historical evidence, Kroll (1996) finds that trading blocks increase the protectionist incentives of members.
} 
free trade agreement and the other member's tariff decreases. ${ }^{2}$ It also finds that a free trade agreement and joint ownership of capital results in one country's tariffs with the rest of the world being lower than when capital is not jointly owned. Another contribution of this article is the establishment of some necessary and sufficient conditions for a free trade agreement to be politically feasible. For example, a necessary condition for a relatively capital abundant country to support a free trade agreement is for the net benefits for capital to be greater under the agreement than under any positive tariff ${ }^{3}$. Positive net benefits to capital under the agreement are also a sufficient condition for a relatively labour abundant country to support a free trade agreement. Together, these results imply that positive net benefits for capital are a necessary condition for a free trade agreement.

Section 4 concludes the paper.

\section{The Model}

It is assumed that the only two factors of production are capital and labour. It is also assumed that owners of factors of production are represented by lobby groups. This paper models the world as consisting of three countries. Country 1 is capital abundant relative to country 2 and country 2 is capital abundant relative to country 3. Country 3 may be thought of as a group of countries representing the rest of the world. For simplicity, it is assumed that the only potential free trade agreement is between country 1 and country 2 . This could be because country 3 is made up of all the remaining countries of the world and trade with any one country is too small to justify any positive negotiation cost involved with a free trade agreement.

A Heckscher-Ohlin framework is assumed. Thus, country 1 will export capitalintensive commodities to countries 2 and 3 and import labour-intensive commodities. Country 2's trade with country 3 will involve the export of relatively capital-intensive goods in exchange for labour-intensive goods.

It is assumed that factors of production are mobile between sectors within a country but are not mobile between countries (at least in the time frame under consideration). Consequently, if the other assumptions of the Heckscher-Ohlin model hold, the Stolper-Samuelson theorem predicts that trade liberalization between countries 1 and 2 will increase the return to capital in country 1 but reduce

\footnotetext{
${ }^{3} \mathrm{Net}$ benefits refer to the benefits to capital in the relatively capital abundant country, minus the costs to capital in the relatively labour abundant country.
} 
it in country 2. Similarly, the return to labour in country 2 will increase from trade liberalization but labour's return in country 1 will decrease. Trade liberalization with country 3 will increase the return to capital in countries 1 and 2 but reduce the return to labour.

The use of the Heckscher-Ohlin framework requires some explanation as it is often thought that protectionist pressures emanate from specific factors models. Indeed, this is likely when the trade legislation involved has a short life span, as factors of production are unlikely to be mobile between sectors of the economy as required by the Heckscher-Ohlin model ${ }^{4}$. However, when trade legislation has a longer life span, factors of production will be more mobile between sectors of the economy. This makes it more likely that the Stolper-Samuelson theorem will hold and that agents will behave accordingly. Indeed, the empirical evidence regarding the behaviour of voters and lobby groups supports this assumption. For empirical evidence that voters cast their ballots as if, they understand the Stolper-Samuelson theorem, the reader is referred to Beaulieu (2002) and Balistreri (1995, 1997). For evidence that lobby groups behave as if the Stolper-Samuelson theorem holds, see Pyne (2000). Dutt and Mitra (2002) use cross country data to show that changes in trade policy are as predicted when the Stolper-Samuelson theorem and the median voter theorem hold. Examples of endogenous trade policy models that make use of the Stolper-Samuelson relationship include Pyne (2006), Magee and Lee (2000), Levy (1997), Yang (1995), Mayer (1993, 1984), Magee, Brock and Young (1989) and Young and Magee (1986). Levy does so in the specific context of free trade agreements.

This article has a rational choice explanation of the internal political processes of the countries involved but simplifies the model by assuming that no bargaining takes place between countries. To do this it assumes that all three countries are members of the World Trade Organization, which administers the General Agreement on Tariffs and Trade (GATT). Article I of GATT includes an unconditional most-favoured-nation requirement that members are prohibited from geographical discrimination in the application of trade barriers. ${ }^{5}$ However, Article

\footnotetext{
${ }^{4}$ See Magee (1980) for evidence that lobby groups behave as the specific factors model would predict when proposed trade legislation has a short expected life span. Beaulieu and Magee (2004) find capital lobby groups behave as the Stolper-Samuelson theorem predicts. However, they find industry trade balances affect the behaviour of labour lobby groups.

${ }^{5}$ For an economic interpretation and evaluation of this clause, see Bagwell and Staiger (1999). For a discussion of the effects this clause has on international bargaining in general, see Ludema (1991).
} 
XXIV states that this restriction does not apply when a group of countries agree to eliminate all mutual trade barriers. ${ }^{6}$ It is assumed that tariffs are the only trade barriers in the world. Since country 1 is importing labour intensive products from both countries 2 and 3, it must have identical tariffs with each country, unless it can negotiate a free trade agreement with one country resulting in mutual tariffs equal to zero. ${ }^{7}$ Since country 2 is importing different goods from countries 1 and 3, it may have different tariffs for each country. It can have one set of tariffs for the capital-intensive goods it imports from country 1 and another set of tariffs for the relatively labour intensive goods it imports from country 3 . This paper assumes that tariffs are never so high as to reverse the terms of trade.

There are two political parties in countries 1 and 2. Each country $i$ has a procapital party $F_{i}$, where $i=1,2$. This is defined as the party with a platform most favourable to capital. Each country also has a pro-labour party $P_{i}$, where $i=1,2$. This is defined as the political party with the platform most favourable to labour. It is assumed that trade policy is the only election issue in countries 1 and 2 . The trade policy of country 3 is assumed to be exogenously determined.

A modified Magee, Brock and Young (1989) framework is used. In this framework, elections are probabilistic. Political contributions (or lobbying expenditures) from the capital lobby increase the chances of the pro-capital party being elected and reduce the probability of the pro-labour party being elected. Likewise, contributions from the labour lobby increase the probability of the prolabour party being elected but decrease the likelihood of the pro-capital party being elected.

This framework also incorporates a Stackelberg leadership pyramid. Political parties are at the top of the pyramid. Political parties within a country are assumed to act as Cournot competitors with respect to each other but as Stackelberg leaders with respect to the country's lobby groups. Lobby groups within a country behave as Stackelberg followers with respect to the political parties and Cournot competitors with respect to each other. Accordingly, political parties decide on their

\footnotetext{
${ }^{6}$ Actually, some specified barriers to trade are permitted. However, for simplicity this paper will assume that there are no exceptions.

${ }^{7}$ The simplest example to consider is where there are two goods in the world and country 1 specializes in the production of the capital-intensive good and imports the labour-intensive good from both countries 2 and 3. With multiple goods, the different capital intensities of countries 2 and 3 may lead to some differences in the commodities country 1 imports from each country. Nonetheless, this paper will assume enough overlap exists to substantially restrict the choice of tariffs on many commodities.
} 
platforms taking into account the reaction of the lobby groups. Then lobby groups choose the level of their campaign contributions. Austen-Smith (1991) has defended this order of moves on the grounds that legal prohibitions exist against paying politicians to adopt given policies. Therefore, political parties must choose their policies before they receive the lobby groups' contributions.

Since country 1 is capital abundant relative to country 2, the Stolper-Samuelson theorem implies that capital owners in country 1 and labourers in country 2 should favour a free trade agreement. Labour in country 1 and capital owners in country 2 should oppose a free trade agreement. This suggests that a free trade agreement should only occur when a pro-capital party is in power in country 1 and a prolabour party is in power in country 2 . However, in the real world there are counter examples. In the case of the Canada-United States Free Trade Agreement neither political party in power (the Republicans in the United States and the Progressive Conservatives in Canada) commanded the support of labour lobby groups. To account for such situations, this article assumes that the capital lobby has endowments in both countries. This could be because a stock market exists, allowing capital owners to hold capital in both countries. It could also be because the capital lobby group represents multinational corporations. ${ }^{8}$ Section 3 shows that this results in the possibility of a free trade agreement when pro-capital parties are elected in both countries.

The behaviour of the labour lobbies is discussed in section 2.A. Section 2.B investigates the behaviour of the capital lobby. Section 2.C examines the pro-labour parties. The strategies of the pro-capital parties in countries 2 and 1 are discussed in sections 2.D and 2.E, respectively.

\section{A. The Labour Lobbies}

First, consider the maximization problem of the labour lobby in country 1 . Lobby groups want to maximize the expected return to their factors, net of lobbying expenditures. Thus, the labour lobby's objective function is written as follows:

$$
\begin{gathered}
\max _{c_{1}^{L}}\left\{p_{1}\left(c_{1}^{K}, c_{1}^{L}\right) L_{1}\left[p_{2} w_{1}^{F F}+\left(1-p_{2}\right) w_{1}^{F P}\right]+\left(1-p_{1}\left(c_{1}^{K}, c_{1}^{L}\right)\right)\right. \\
\left.L_{1}\left[p_{2} w_{1}^{P F}+\left(1-p_{2}\right) w_{1}^{P P}\right]-c_{1}^{L}\right\}
\end{gathered}
$$

\footnotetext{
${ }^{8}$ Hillman and Ursprung (1993) have also studied the effect of multinational firms on endogenous trade policy. Grossman and Helpman (1996) and Leidy (1994) discuss the effects of direct foreign investment on endogenous trade policy.
} 
such that $c_{1}^{L} \geq 0$.

where $c_{1}^{L}=$ the lobbbying expenditures of the labour lobby in country 1

$c_{1}^{K}=$ the lobbbying expenditures of the labour lobby in country 1

$p_{1}=$ the probability of party $F_{1}$ winning the election in country 1

$L_{1}=$ the endowment of the labour lobby in country 1

$w_{1}^{g h}=$ the return to labour in country 1 if party $h_{2}\left(h_{2}=P_{2}, F_{2}\right)$ wins the election in country 2 and party $g_{1}\left(g_{1}=P_{1}, F_{1}\right)$ wins the election in country 1

$p_{2}=$ the probability of party $F_{2}$ winning the election in country 2

In the above, $p_{2}$ is taken as given by the labour lobby in country 1 . When the election in country 2 has already occurred, $p_{2}$ will equal either zero or one. $0 \leq p_{2} \leq 1$ is the general case which can model situations such as the Canadian and American elections in 1988 which took place within a few days of each other. Following Magee, Brock and Young's (1989) original framework, campaign contributions are assumed to come out of some numeraire good whose value is unaffected by trade policy. This is largely done for simplicity.

Assuming an interior solution, the first order condition is

$$
\frac{\partial p_{1}\left(c_{1}^{K}, c_{1}^{L}\right)}{\partial c_{1}^{L}} L_{1} \Delta w_{1}=1
$$

where $\Delta w_{1}=p_{2}\left(w_{1}^{F F}-w_{1}^{P F}\right)+\left(1-p_{2}\right)\left(w_{1}^{F P}-w_{1}^{P P}\right)$

In the above, $\Delta w_{1}$ is the expected difference in the return to labour in country 1 under the two possible political regimes. If party $P_{1}$ is the labour lobby's most favoured party, it follows that $w_{1}^{F F}-w_{1}^{P F} \leq 0$ and $w_{1}^{F P}-w_{1}^{P P} \leq 0$. Thus, $\Delta w_{1}<0$. Hence, a necessary condition for the first order condition to hold is $\partial p_{1} / \partial c_{1}^{L}<0$. Equation (2) is simply the familiar efficiency condition that the labour lobby will choose $c_{1}^{L}$ such that the marginal benefit from an increase in lobbying expenditures is equal to its marginal cost.

The second order condition is

$$
\frac{\partial^{2} p_{1}\left(c_{1}^{K}, c_{1}^{L}\right)}{\partial\left(c_{1}^{L}\right)^{2}} L_{1} \Delta w_{1}=S<0
$$


$\partial^{2} p_{1}\left(c_{1}^{K}, c_{1}^{L}\right) / \partial\left(c_{1}^{L}\right)^{2} \geq 0$ is a necessary second order condition for a maximum.

For use in later sections, this paper now examines the relationship between the expected differences in factor returns under the two possible domestic political regimes and the contributions of the lobby groups. To do this, equation (2) is totally differentiated with respect to $c_{1}^{L}$ and $\Delta w_{1}$. Then, the result is solved for $d c_{1}^{L} / d\left(\Delta w_{1}\right)$ :

$$
\frac{d c_{1}^{L}}{d\left(\Delta w_{1}\right)}=-\frac{\frac{\partial p_{1}\left(c_{1}^{K}, c_{1}^{L}\right)}{\partial c_{1}^{L}} L_{1}}{S}
$$

Since $\partial p_{1} / \partial c_{1}^{L}<0$ and $S<0$, it follows that $d c_{1}^{L} / d\left(\Delta w_{1}\right)<0$. When you recall that $\Delta w_{1}<0$, this is intuitive. As the relative damage of the pro-capital party gets smaller, $\Delta w_{1}$ becomes less negative (larger) and there is less incentive for the labour lobby to donate to the pro-labour party.

The maximization problem of the labour lobby in country 2 is given below:

$$
\begin{gathered}
\max _{c_{2}^{L}}\left\{p_{2}\left(c_{2}^{K}, c_{2}^{L}\right) L_{2}\left[p_{1} w_{2}^{F F}+\left(1-p_{1}\right) w_{2}^{P F}\right]+\left(1-p_{2}\left(c_{2}^{K}, c_{2}^{L}\right)\right)\right. \\
\left.L_{2}\left[p_{1} w_{2}^{F P}+\left(1-p_{1}\right) w_{2}^{P P}\right]-c_{2}^{L}\right\}
\end{gathered}
$$

such that $c_{2}^{L} \geq 0$

where $c_{2}^{L}=$ the lobbbying expenditures of the labour lobby in country 2

$c_{2}^{K}=$ the lobbbying expenditures of the labour lobby in country 2

$L_{2}=$ the endowment of the labour lobby in country 2

$w_{2}^{g h}=$ the return to labour in country 2 if party $h_{2}\left(h_{2}=P_{2}, F_{2}\right)$ wins the election in country 2 and party $g_{1}\left(g_{1}=P_{1}, F_{1}\right)$ wins the election in country 1

In the above, the labour lobby in country 2 takes $p_{1}$ as given. Assuming an interior solution, the first order condition is

$$
\frac{\partial p_{2}\left(c_{2}^{K}, c_{2}^{L}\right)}{\partial c_{2}^{L}} L_{2} \Delta w_{2}=1
$$

where $\Delta w_{2}=p_{1}\left(w_{2}^{F F}-w_{2}^{F P}\right)+\left(1-p_{1}\right)\left(w_{2}^{P F}-w_{2}^{P P}\right)$

If party $P_{2}$ is the party most favourable to labour, it follows $w_{2}^{F F}-w_{2}^{F P} \leq 0$ that 
and $w_{2}^{P F}-w_{2}^{P P} \leq 0$. Thus, $\Delta w_{2}<0$. Therefore, it follows that $\partial p_{2} / \partial c_{2}^{L}<0$ (otherwise, the labour lobby would set $c_{2}^{L}=0$ ). Equation (6) simply says that the marginal benefit from an increase in lobbying expenditures should equal its marginal cost.

The second order condition is

$$
\frac{\partial^{2} p_{2}\left(c_{2}^{K}, c_{2}^{L}\right)}{\partial\left(c_{2}^{L}\right)^{2}} L_{2} \Delta w_{2}<0
$$

$\partial^{2} p_{2}\left(c_{2}^{K}, c_{2}^{L}\right) / \partial\left(c_{2}^{L}\right)^{2} \geq 0$ is a necessary condition for a maximum.

As with the pro-labour party in country 1 , it can be shown that $d c_{2}^{L} / d\left(\Delta w_{2}\right)<0$.

\section{B. The Capital Lobby}

The problem the capital lobby faces is more complex than that facing the labour lobbies. A reduction in tariffs between countries 1 and 2 increases the return to capital in country 1 but it reduces the return to capital in country 2 . Thus, the capital lobby considers this interrelationship in the returns to capital when deciding on its lobbying expenditures in each country. Therefore, its optimization problem is

$$
\begin{aligned}
\max _{c_{1}^{K}, c_{2}^{K}} & \left\{p_{1}\left(c_{1}^{K}, c_{1}^{L}\right)\left[p_{2}\left(c_{2}^{K}, c_{2}^{L}\right) r_{1}^{F F}+\left(1-p_{2}\left(c_{2}^{K}, c_{2}^{L}\right)\right) r_{1}^{F P}\right] K_{1}\right. \\
& +\left(1-p_{1}\left(c_{1}^{K}, c_{1}^{L}\right)\right)\left[p_{2}\left(c_{2}^{K}, c_{2}^{L}\right) r_{1}^{P F}+\left(1-p_{2}\left(c_{2}^{K}, c_{2}^{L}\right)\right) r_{1}^{P P}\right] K_{1} \\
& +p_{2}\left(c_{2}^{K}, c_{2}^{L}\right)\left[p_{1}\left(c_{1}^{K}, c_{1}^{L}\right) r_{2}^{F F}+\left(1-p_{1}\left(c_{1}^{K}, c_{1}^{L}\right)\right) r_{2}^{P F}\right] K_{2} \\
& \left.\left.+\left(1-p_{2}\left(c_{2}^{K}, c_{2}^{L}\right)\right)\left[p_{1}\left(c_{1}^{K}, c_{1}^{L}\right)\right) r_{2}^{F P}+\left(1-p_{1}\left(c_{1}^{K}, c_{1}^{L}\right)\right) r_{2}^{P P}\right] K_{2}-c_{1}^{K}-c_{2}^{K}\right\}
\end{aligned}
$$

such that $c_{1}^{K} \geq 0$

$$
c_{2}^{K} \geq 0
$$

where $K_{1}=$ the endowment of the capital lobby in country 1

$K_{2}=$ the endowment of the capital lobby in country 2

$r_{i}^{g h}=$ the return to labour in country $i$ if party $h_{2}\left(h_{2}=F_{2}, P_{2}\right)$ wins the election in country 2 and party $g_{1}\left(g_{1}=F_{1}, P_{1}\right)$ wins the election in country 1

The first order conditions are as follows:

$$
\frac{\partial p_{1}\left(c_{1}^{K}, c_{1}^{L}\right)}{\partial c_{1}^{K}}\left[K_{1} \Delta r_{1}^{1}+K_{2} \Delta r_{2}^{1}\right]=1
$$




$$
\frac{\partial p_{2}\left(c_{2}^{K}, c_{2}^{L}\right)}{\partial c_{2}^{K}}\left[K_{1} \Delta r_{1}^{2}+K_{2} \Delta r_{2}^{2}\right]=1
$$

where

$$
\begin{aligned}
& \Delta r_{2}^{2}=p_{1} r_{2}^{F F}+\left(1-p_{1}\right) r_{2}^{P F}-p_{1} r_{2}^{F P}-\left(1-p_{1}\right) r_{2}^{P P} \\
& \Delta r_{1}^{2}=p_{1} r_{1}^{F F}+\left(1-p_{1}\right) r_{1}^{P F}-p_{1} r_{1}^{F P}-\left(1-p_{1}\right) r_{1}^{P P} \\
& \Delta r_{2}^{1}=p_{2} r_{2}^{F F}+\left(1-p_{2}\right) r_{2}^{F P}-p_{2} r_{2}^{F P}-\left(1-p_{2}\right) r_{2}^{P P} \\
& \Delta r_{1}^{1}=p_{2} r_{1}^{F F}+\left(1-p_{2}\right) r_{1}^{F P}-p_{2} r_{1}^{P F}-\left(1-p_{2}\right) r_{1}^{P P}
\end{aligned}
$$

In the above, $\Delta r_{i}^{j}$ is the difference in expected returns to capital in country $i$ from party $F_{j}$ being elected in country $j$ rather than party $P_{j}$. The terms in square brackets is interpreted as the net benefit from party $F_{j}$ being elected in country $j$ minus the net benefit of party $P_{j}$ being elected instead. "Net" because an increase in the tariffs one country imposes on the other will increase the return to capital in country 2 but reduce it in country 1 . Note that necessary conditions for a maximum include $\partial p_{1}\left(c_{1}^{K}, c_{1}^{L}\right) / \partial\left(c_{1}^{K}\right)>0$ (if $\left.\left[K_{1} \Delta r_{1}^{1}+K_{2} \Delta r_{2}^{1}\right]>0\right), \partial p_{2}\left(c_{2}^{K}, c_{2}^{L}\right) / \partial\left(c_{2}^{K}\right)>0$ (assuming $\left.\left.\left[K_{1} \Delta r_{1}^{2}+K_{2} \Delta r_{2}^{2}\right]>0\right), \partial^{2} p_{1}\left(c_{1}^{K}, c_{1}^{L}\right) / \partial\left(c_{1}^{K}\right)^{2}<0\right)$, and $\partial^{2} p_{2}\left(c_{2}^{K}, c_{2}^{L}\right) /$ $\partial\left(c_{2}^{K}\right)^{2}<0$. Also, note that examination of the first order conditions reveal that $C_{i}^{K}$ is a positive function of the net benefits of having $F_{i}$ elected.

It is assumed that the second order conditions hold.

\section{The Pro-labour Parties}

From the prospective of the political parties, factor returns are a function of the tariff rates they choose. The returns in country 1 are written as follows:

$$
\begin{gathered}
r_{1}=r_{1}\left(t_{1}^{2}, t_{1}^{3}, t_{2}^{1}, t_{2}^{3}\right) \\
w_{1}=w_{1}\left(t_{1}^{2}, t_{1}^{3}, t_{2}^{1}, t_{2}^{3}\right)
\end{gathered}
$$

where $t_{1}^{2}=$ the tariff country 1 imposes on its imports from country 2

$t_{1}^{3}=$ the tariff country 1 imposes on its imports from country 3

$t_{2}^{1}=$ the tariff country 2 imposes on its imports from country 1

$t_{2}^{3}=$ the tariff country 2 imposes on its imports from country 3

In the above $t_{j}^{i}$, is the tariff country $j$ imposes on imports from country $i(i \neq j, i$, 
$j=\{1,2,3\})$. Since country 1 is capital intensive relative to the rest of the world and the Stolper-Samuelson theorem is assumed to hold, it follows that $\partial r_{1} / \partial t_{1}^{2}<0, \partial r_{1} / \partial t_{2}^{1}<0$ and $\partial r_{1} / \partial t_{1}^{3}<0$. Similarly, $\partial w_{1} / \partial t_{1}^{2}>0, \partial w_{1} / \partial t_{2}^{1}>0$ and $\partial w_{1} / \partial t_{1}^{3}>0$. The signs of $\partial w_{1} / \partial t_{2}^{3}$ and $\partial r_{1} / \partial t_{2}^{3}$ are determined in section 3.C. The factor returns in country 2 are given below:

$$
\begin{gathered}
r_{2}=r_{2}\left(t_{1}^{2}, t_{1}^{3}, t_{2}^{1}, t_{2}^{3}\right) \\
w_{2}=w_{2}\left(t_{1}^{2}, t_{1}^{3}, t_{2}^{1}, t_{2}^{3}\right)
\end{gathered}
$$

Country 2 is assumed to be labour abundant relative to country 1 . Therefore, using the Stolper-Samuelson theorem we know that $\partial r_{2} / \partial t_{1}^{2}>0, \partial r_{2} / \partial t_{2}^{1}>0$, $\partial w_{2} / \partial t_{1}^{2}<0$ and $\partial w_{2} / \partial t_{2}^{1}<0$. Since country 2 is capital abundant relative to country 3 , it follows that $\partial r_{2} / \partial t_{2}^{3}<0$ and $\partial w_{2} / \partial t_{2}^{3}>0$. The signs of $\partial r_{2} / \partial t_{1}^{3}$ and $\partial w_{2} / \partial t_{1}^{3}$ are ambiguous.

Each political party in a country will treat the contributions of the lobby groups as a function of the differences in the expected rates of return under its regime and those of its opponent. Since political parties are Stackelberg leaders with respect to the lobby groups within their country, they will also consider how one lobby group's expenditures respond to changes in the expenditures of the other lobby group. Therefore, we can write the contribution of the labour lobby to party $P_{2}$ in country 2 as

$$
c_{2}^{L}=c_{2}^{L}\left(\Delta w_{2}, c_{2}^{K}\right)
$$

Likewise, the contribution function of the labour lobby in country 1 can be written as

$$
c_{1}^{L}=c_{1}^{L}\left(\Delta w_{1}, c_{1}^{K}\right)
$$

Thus, it follows that $\partial c_{i}^{L} / \partial\left(\Delta w_{i}\right)<0$, where $i=1,2$.

The contribution function of the capital lobby is slightly more complex. This is because the capital lobby considers the effects of the tariff structure in country $i$ on its capital holdings in country $j$. Its contribution functions are given below:

$$
c_{1}^{K}=c_{1}^{K}\left(\Delta r_{1}^{1}, \Delta r_{2}^{1}, c_{1}^{L}\right)
$$




$$
c_{2}^{K}=c_{2}^{K}\left(\Delta r_{1}^{2}, \Delta r_{2}^{2}, c_{2}^{L}\right)
$$

First, consider the maximization problem of party $P_{2}$. It first has to decide whether to try to obtain a free trade agreement with country 1 . It then has to decide on a tariff vector to propose. If it decides to attempt to obtain a free trade agreement with country 1 and is successful, it only has to choose values for $t_{2}^{3}$. It may choose two values of $t_{2}^{3}$, each contingent on a different party winning in country 1 . These values may differ depending on the effects of $t_{1}^{3}$ on factor returns in country 2. It must also decide what tariff rate it will introduce, if it is unable to obtain a free trade agreement with country 1 . If $P_{2}$ decides not to try to obtain a free trade agreement with country 1 , it must choose values for both $t_{2}^{1}$ and $t_{2}^{3}$. It may choose different values of these variables contingent on which party wins the election in country 1 . Let ${ }^{F P} t_{2}^{i}$ represent country 2 's tariff rate on imports from country $i(i=1,3)$ if party $F_{1}$ wins the election in country 1 and party $P_{2}$ wins the election in country 2 . Let ${ }^{P P} t_{2}^{i}$ represent country 2 's tariff rate on imports from country $i(i=1,3)$ if party $P_{1}$ wins the election in country 1 and party $P_{2}$ wins the election in country 2 . Assume that in each case, $P_{2}$ chooses the tariff structure that maximizes its probability of election. Thus, $P_{2}$ solves each maximization problem and then chooses the option (free trade agreement or no agreement) which maximizes its probability of election.

In the remainder of this paper, the following vector notation is used:

$$
\begin{array}{ll}
\mathbf{t}^{g h}=\left({ }^{g h} t_{1}^{2},{ }^{g h} t_{1}^{3},{ }^{g h} t_{2}^{1},{ }^{g h} t_{2}^{3}\right) & \\
\mathbf{t}_{0}^{g h}=\left({ }^{g h} t_{1}^{2}=0,{ }^{g h} t_{1}^{3},{ }^{g h} t_{2}=0,{ }^{g h} t_{2}^{3}\right) & \text { for } g, h=F, P
\end{array}
$$

In other words, $\mathbf{t}^{\text {gh }}$ is the tariff vector resulting from the election of party $g_{1}$ in country 1 and party $h_{2}$ in country 2 , where $g_{1}=F_{1}, P_{1}$ and $h_{2}=F_{2}, P_{2}$. A subscript 0 indicates that $t_{1}^{2}=t_{2}^{1}=0$ (as would result from a free trade agreement).

First, consider the case where $P_{2}$ does not try to obtain a free trade agreement with country 1 . Since there are only two political parties in each country, when $P_{2}$

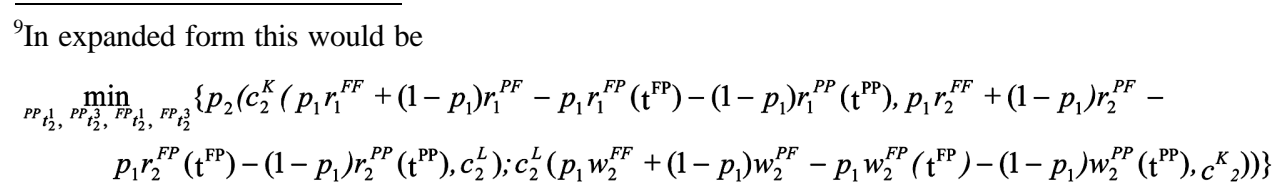

In future, the expanded form will not be explicitly given. 
maximizes its probability of election it is minimizing the probability of $F_{2}$ being elected. Thus, it faces the following minimization problem ${ }^{9}$ :

$$
\min _{P P_{t_{2}}^{1}, P P_{2}^{3}, F P_{2}^{1}, F P_{t}^{3}}\left\{p_{2}\left(c_{2}^{K}\left(\Delta r_{1}^{2}, \Delta r_{2}^{2}, c_{2}^{L}\right), c_{2}^{L}\left(\Delta w_{2}, c_{2}^{K}\right)\right)\right\}
$$

Assuming an interior solution, its first order conditions are given below:

$$
\frac{\partial p_{2}}{\partial c_{2}^{L}} \frac{d c_{2}^{L}}{d^{j P} t_{2}^{i}}=-\frac{\partial p_{2}}{\partial c_{2}^{K}} \frac{d c_{2}^{K}}{d^{j P} t_{2}^{i}} \text { for } i=1,3 \wedge j=F, P
$$

where ${ }^{j P} t_{2}^{i} \in t^{j P}$

Since the lobbying levels of all four lobby groups are determined simultaneously and are all interrelated, to determine the sign of $\partial c_{2}^{K} / d^{j P} t_{2}^{i}$ (for $i=1,3$ and $j=F, P$ ), one could consider the four first-order conditions of the lobby groups in both countries. They could each be totally differentiated with respect to the four lobbying expenditures and ${ }^{j P} t_{2}^{i}$. The resulting system of simultaneous equations could be solved to determine the sign of $d c_{2}^{K} / d^{j P} t_{2}^{i}$. However, this would involve making a number of arbitrary assumptions regarding the signs and relative magnitudes of the derivatives involved. Thus, instead this paper merely assumes that both $d c_{2}^{K} / d^{g P} t_{2}^{3}$ and $d c_{2}^{L} / d^{g P} t_{2}^{3}\left(d c_{2}^{K} / d^{g P} t_{2}^{1}\right.$ and $\left.d c_{2}^{L} / d^{g P} t_{2}^{1}\right)$ are greater (less) than zero. Therefore, the left side of equation (21) is the marginal benefit, in terms of an increased likelihood of election, from an increase (decrease in the case of $\left.{ }^{g P} t_{2}^{1}\right)$ in ${ }^{g P} t_{2}^{3}\left({ }^{g P} t_{2}^{1}\right)$. The right side is the net marginal cost to party $P_{2}$ of an increase (decease) in ${ }^{g P} t_{2}^{3}\left({ }^{g P} t_{2}^{1}\right)$.

It is assumed that the second order conditions of party $P_{2}$ (and the other political parties) hold.

Now consider the case where party $P_{2}$ decides to try to negotiate a free trade agreement with country 1 . It will only be successful if the party elected in country 1 supports a free trade agreement. In case the party elected in country 1 does not support a free trade agreement, it must state a set of tariffs contingent on not being able to negotiate a free trade agreement. Assume that $P_{2}$ will be able to negotiate a free trade agreement with country 1 if and only if party $F_{1}$ is elected in country 1 . Then party $P_{2}$ faces the following problem:

$$
\min _{{ }^{P P} t_{t_{2}^{\prime}}^{\prime},{ }^{P} t_{2}^{3},{ }^{F P} t_{2}^{3}}\left\{p_{2}\left(c_{2}^{K}\left(\Delta r_{1}^{2}, \Delta r_{2}^{2}, c_{2}^{L}\right), c_{2}^{L}\left(\Delta w_{2}, c_{2}^{K}\right)\right)\right\}
$$


This problem yields first order conditions, similar in appearance to equation (21), which implicitly define the optimal levels of ${ }^{F P} t_{2}^{3} \in \mathbf{t}_{0}^{F P}$ and ${ }^{F P} t_{2}^{i} \in \mathbf{t}_{0}^{P P} \quad(i=2$, 3).

Party $P_{2}$ will compare the optimal tariff vectors of problems (20) and (22). It then chooses the set of tariffs that give it the highest probability of election.

Now consider the problem of party $P_{1}$. Like party $P_{2}$ it must decide whether to seek a free trade agreement. Since country 1 is relatively capital abundant, labour in country 1 is hurt by trade liberalization. Thus, it is unlikely that pro-labour party $P_{1}$ will attempt to obtain a free trade agreement with country $2 .{ }^{10}$ If it does not seek a free trade agreement with country 2 , it must choose a set of proposed tariffs contingent on the outcome of the election in country 2. However, unlike political parties in country 2, it must choose a set of proposed tariffs such that $t_{1}^{2}=t_{1}^{3}$. This is because country 1 is importing the same goods from country 2 and country 3 . When it decides not to negotiate a free trade agreement, its optimization problem is

$$
\min _{P F_{t_{1}}^{2}, P F_{t_{1}^{3}}^{3}, P P_{t_{1}^{2}}^{2}, P P_{t_{1}^{3}}^{3}}\left\{p_{1}\left(c_{1}^{K}\left(\Delta r_{1}^{1}, \Delta r_{2}^{1}, c_{1}^{L}\right), c_{1}^{L}\left(\Delta w_{1}, c_{1}^{K}\right)\right)\right\}
$$

such that $t_{1}^{2}=t_{1}^{3}$

from which optimal levels of ${ }^{P h} t_{1}{ }_{1} \in \mathbf{t}^{P h}$ (for $h=P, F$ and $i=2,3$ ) can be determined.

\section{The Pro-capital Party in Country 2}

Like party $P_{2}$, party $F_{2}$ must decide whether to attempt to obtain a free trade agreement with country 1 . Like party $P_{2}$, it does this by solving two different maximization problems and choosing the set of contingent tariffs which gives it the greatest probability of winning the election.

First, consider the case where $F_{2}$ decides not to try to obtain a free trade agreement with country 1 . Its maximization problem is given below:

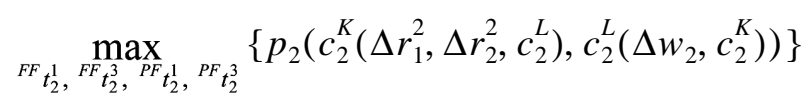

This problem determines the optimal levels of ${ }^{g F} t_{2}{ }^{i} \in \mathbf{t}^{g F}$ (for $i=1,3$ and $g=P, F$ ).

Now consider the case where party $F_{2}$ decides to negotiate a free trade agreement with country 1 . As with party $P_{2}$, it is assumed that it will be possible to

$\overline{{ }^{10}}$ The case where party $P_{1}$ does attempt a free trade agreement with country 2 is considered in section 3.B. 
negotiate a free trade agreement with country 1 if, and only if, party $F_{1}$ is successful in the electoral competition in country 1 . Party $F_{2}$ 's problem is given below:

$$
\max _{{ }^{F F} t_{2}^{3},{ }^{P} t_{2}^{1}, P F_{2}^{3}}\left\{p_{2}\left(c_{2}^{K}\left(\Delta r_{1}^{2}, \Delta r_{2}^{2}, c_{2}^{L}\right), c_{2}^{L}\left(\Delta w_{2}, c_{2}^{K}\right)\right)\right\}
$$

The solution to this problem defines party $F_{2}$ 's optimal levels of ${ }^{F F} t_{2}{ }^{3} \in \mathbf{t}_{0}^{\text {Fh }}$ and ${ }^{P F} t_{2}^{i} \in \mathbf{t}_{0}^{\mathbf{P F}}(i=1,3)$.

The pro-capital party in country 2 will compare the probability of winning an election with the optimal proposed tariffs from each maximization problem. It will decide to propose a free trade agreement with country 2 if the probability of electoral success is greater with a free trade agreement.

\section{E. The Pro-capital Party in Country 1}

Party $F_{1}$ is a key player in this model. It is the party in country 1 most likely to support a free trade agreement. Like the other political parties, it must decide whether to attempt to negotiate a free trade agreement. It does this by comparing the outcomes of maximization problems with and without free trade.

First, consider the case where $F_{1}$ decides not to negotiate a free trade agreement with country 2 . Its maximization problem is

$$
\max _{{ }^{F F} t_{1}^{2},{ }^{F T_{1}^{3}},{ }^{F P} t_{1}^{2},{ }^{F P} t_{1}^{3}}\left\{p_{1}\left(c_{1}^{K}\left(\Delta r_{1}^{1}, \Delta r_{2}^{1}, c_{1}^{L}\right), c_{1}^{L}\left(\Delta w_{1}, c_{1}^{K}\right)\right)\right\}
$$

such that ${ }^{F F} t_{1}^{2}={ }^{F F} t_{1}^{3}$ and ${ }^{F P} t_{1}^{2}={ }^{F P} t_{1}^{3}$

The solution gives the optimal level of ${ }^{F h} t_{1}^{i} \in \mathbf{t}^{\mathbf{F h}}(h=F, P)$ when party $F_{1}$ does not try to negotiate a free trade agreement.

To include the possibility of a free trade agreement in the platform of party $F_{1}$, there are two possibilities to consider. One is when only one party in country 2 is willing to accept a free trade agreement. The other is where both parties are willing to accept a free trade agreement. However, section 3 will show that the former case is unlikely when $F_{1}$ supports a free trade agreement. Thus, only the latter case is considered here. In this case, equation (27) is the objective function of party $F_{1}$ :

$$
\max _{{ }^{F F} t_{1}^{3}{ }^{P} P_{1}^{3}}\left\{p_{1}\left(c_{1}^{K}\left(\Delta r_{1}^{1}, \Delta r_{2}^{1}, c_{1}^{L}\right), c_{1}^{L}\left(\Delta w_{1}, c_{1}^{K}\right)\right)\right\}
$$


From this problem the optimal values of ${ }^{F h} t_{1}^{3} \in \mathbf{t}_{0}^{\mathbf{F h}}$ (for $h=P, F$ ) can be determined.

\section{Analysis}

This section discusses various implications of the model presented in section 2 . Section 3.A presents several necessary conditions for the pro-capital party in country 1 to be willing to propose a free trade agreement with country 2 . It also examines the effects of a free trade agreement on country 1's tariff with country 3 when its pro-capital party is in power. Section 3.B discusses necessary conditions for party $P_{1}$ to propose a free trade agreement with country 2 . It also shows that country 1 's tariff with country 3 will increase with a free trade agreement when country 1's pro-labour party is in power. Section 3.C presents some sufficient conditions for political parties in country 2 to support a free trade agreement. It also examines the effect free trade has on country 2's tariff with country 3. Section 3.D examines the effect of capital in both countries being owned by the same lobby group has on tariffs with the rest of the world when a free trade agreement is negotiated. It finds that at least one of the two countries will have lower tariffs with the rest of the world when the same lobby group represents capital in both countries. These results should enlighten current public debates on the effects trade pacts have on trade restrictions with non-member countries. This section also examines the effect of having a common capital lobby in both countries on the likelihood of a free trade agreement. It finds that this increases the likelihood of country 2 supporting a free trade agreement but reduces the probability of country 1 supporting an agreement.

\section{A. Pro-capital Party in Country 1}

This section presents two conditions for proposing a free trade agreement to be an equilibrium strategy for party $F_{1}$. It also discusses the effect a free trade agreement has on the value of $t_{1}^{3}$ party $F_{1}$ chooses.

First, consider the case where party $F_{1}$ does not take into account the effect its tariff rate has on the tariffs in country 2 . The assumption that the political parties in country 1 are Cournot competitors is retained. To simplify the analysis, assume that the election in country 2 has already occurred so the value of $p_{2}$ is either zero or one. Furthermore, assume that the party elected in country 2 is willing to negotiate a free trade agreement with country 1 . Further, assume that all optimal tariffs from 
the maximization problems are nonnegative. Recall that GATT requires country 1 to impose the same tariffs on country 2 as it imposes on country 3 . To simplify the notation, note that for party $F_{1}, p_{1}$ is implicitly a direct function of the tariff rates it chooses. Thus, its maximization problem, when it decides not to negotiate a free trade agreement, can be written as

such that ${ }^{F} t_{1}^{2}={ }^{F} t_{1}^{3}$

$$
\max _{F_{F_{1}^{2}}^{2}, F_{1}^{3}} p_{1}\left({ }^{F} t_{1}^{2}, t_{1}^{3}\right)
$$

where ${ }^{F} t_{1}^{j}=$ party $F_{1}$ 's proposed tariff with country $j(j=2,3)$

This results in the following first order condition:

$$
\frac{\partial p_{1}\left({ }^{F} t_{1}^{2},{ }^{F} t_{1}^{3}\right)}{\partial^{F} t_{1}^{2}}+\frac{\left.\partial p_{1}{ }^{F} t_{1}^{2},{ }^{F} t_{1}^{3}\right)}{\partial^{F} t_{1}^{3}}=0
$$

Sufficient conditions for a maximum include $\partial^{2} p_{1}\left({ }^{F} t_{1}^{2},{ }^{F} t_{1}^{3}\right) / \partial\left({ }^{F} t_{1}^{2}\right)^{2}<0$, $\partial^{2} p_{1}\left({ }^{F} t_{1}^{2},{ }^{F} t_{1}^{3}\right) / \partial\left({ }^{F} t_{1}^{3}\right)^{2}<0$, and $\partial^{2} p_{1}\left({ }^{F} t_{1}^{2},{ }^{F} t_{1}^{3}\right) / \partial^{F} t_{1}^{2} \partial^{F} t_{1}^{3} \leq 0$. This section assumes that $\partial^{2} p_{1}\left({ }^{F} t_{1}^{2},{ }^{F} t_{1}^{3}\right) / \partial^{F} t_{1}^{2} \partial^{F} t_{1}^{3}=0$

When party $F_{1}$ country 1 chooses the free trade agreement option, its optimization problem is

$$
\max _{F_{t_{1}^{3}}^{3}} p_{1}\left({ }^{F} t_{1}^{2}=0,{ }^{F} t_{1}^{3}\right)
$$

Assuming an interior solution, its first order condition is given by equation (31):

$$
\frac{\partial p_{1}\left({ }^{F} t_{1}^{2}=0,{ }^{F} t_{1}^{3}\right)}{\partial^{F} t_{1}^{3}}=0
$$

A sufficient second order condition for a maximum is $\partial^{2} p_{1}\left({ }^{F} t_{1}^{2}=0,{ }^{F} t_{1}^{3}\right) / \partial\left({ }^{F} t_{1}^{3}\right)^{2}<0$

Lemma 1 discusses a necessary condition for a free trade agreement to be a preferred alternative for party $F_{1}$ :

LEMMA 1: Suppose $F_{1}$ acts as a Cournot competitor. Further assume that all optimal tariffs are nonnegative and that $\partial^{2} p_{1}\left({ }^{F} t_{1}^{2},{ }^{F} t_{1}^{3}\right) / \partial^{F} t_{1}^{2} \partial^{F} t_{1}^{3}=0$ In addition, assume that $p_{1}\left({ }^{F} t_{1}^{2},{ }^{F} t_{1}^{3}\right)$ has unique maximum values of ${ }^{F} t_{1}^{2}$ and ${ }^{F} t_{1}^{3}$ (is strictly concave), given the proposed tariffs of party $P_{1}$. A necessary condition for a free trade agreement to be an equilibrium is for $\partial p_{1}\left({ }^{F} t_{1}^{2},{ }^{F} t_{1}^{3}\right) / \partial^{F} t_{1}^{2}<0$ and $\partial p_{1}\left({ }^{F} t_{1}^{2}, F^{3} t_{1}^{3}\right) / \partial^{F} t_{1}^{3}>0$, at the solution to problem (28).

PROOF: From equation (29) it is clear that $\partial p_{1}\left({ }^{F} t_{1}^{2},{ }^{F} t_{1}^{3}\right) / \partial^{F} t_{1}^{2}$ and 
$\partial p_{1}\left({ }^{F} t_{1}^{2},{ }^{F} t_{1}^{3}\right) / \partial^{F} t_{1}^{3}$ must either both be equal to zero or have opposite signs. If they are equal to zero and the assumptions of the lemma hold, no other proposed tariff vector (including the free trade agreement tariff vector) can improve party $F_{\mathrm{i}}$ 's election chances. There are two remaining possibilities to consider.

Case 1: $\partial p_{1}\left({ }^{F} t_{1}^{2},{ }^{F} t_{1}^{3}\right) / \partial^{F} t_{1}^{2}>0$ and $\partial p_{1}\left({ }^{F} t_{1}^{2},{ }^{F} t_{1}^{3}\right) / \partial^{F} t_{1}^{3}<0$.

Let $\left({ }^{F} t,{ }^{F} t\right)$ be the ${ }^{F} t_{1}^{2},{ }^{F} t_{1}^{3}$ pair that maximizes political support without a free trade agreement. The assumption that the cross-partial is zero implies that the optimal value of ${ }^{F} t_{1}^{3}$ is some ${ }^{F} T$ in $\left(0,{ }^{F} t\right)$ (independent of the value of $\left.{ }^{F} t_{1}^{2}\right)$. So under a free trade agreement, party $F_{1}$ will pick ${ }^{F} t_{1}^{3}={ }^{F} T<{ }^{F} t$. Concavity also means that support is increasing in ${ }^{F} t_{1}^{2}$ for $0 \leq{ }^{F} t_{1}^{2} \leq{ }^{F} t$.

So $\left({ }^{F} T,{ }^{F} T\right)$ would get more support than $\left(0,{ }^{F} T\right)$. The fact that $\left({ }^{F} T,{ }^{F} T\right)$ is feasible when a free trade agreement is not entered into shows that $\left({ }^{F} t,{ }^{F} t\right)$ is preferred to $\left({ }^{F} T,{ }^{F} T\right)$. Therefore, the free trade agreement option will not be chosen.

Case 2: $\partial p_{1}\left({ }^{F} t_{1}^{2},{ }^{F} t_{1}^{3}\right) / \partial^{F} t_{1}^{2}<0$ and $\partial p_{1}\left({ }^{F} t_{1}^{2},{ }^{F} t_{1}^{3}\right) / \partial^{F} t_{1}^{3}>0$.

Since $\partial p_{1}\left({ }^{F} t_{1}^{2},{ }^{F} t_{1}^{3}\right) / \partial^{F} t_{1}^{2}<0$, a decrease in ${ }^{F} t_{1}^{2}$ could increase the probability of election. Similarly, an increase in ${ }^{F} t_{1}^{3}$ will increase the probability of electoral success. Note that this is only a necessary and not a sufficient condition for a free trade agreement. It is not a sufficient condition because ${ }^{F} t_{1}^{2}=0$ may be past the optimal level that ${ }^{F} t_{1}^{2}$ would have if its value were not restricted. However, even if ${ }^{F} t_{1}^{2}=0$ is past the optimal level of ${ }^{F} t_{1}^{2}$, it is still possible that a free trade agreement is an equilibrium (but not assured).

Q.E.D.

The assumption that $\partial^{2} p_{1}\left({ }^{F} t_{1}^{2},{ }^{F} t_{1}^{3}\right) / \partial^{F} t_{1}^{2} \partial^{F} t_{1}^{3}=0$ is not necessary for the above result to hold but it is sufficient. ${ }^{11}$

Lemma 1 is used to establish theorem 1 . Theorem 1 states that a free trade agreement will raise country 1 's tariff with country 3 when party $F_{1}$ is in power in country 1 :

THEOREM 1: Given the assumptions of lemma 1, with a free trade agreement between countries 1 and $2,{ }^{F} t_{1}^{3}$ is higher than it would be without a free trade agreement. $^{12}$

\footnotetext{
${ }^{11}$ Citing the tariff complementarity effect, an anonymous referee pointed out that this partial derivative is unlikely to be exactly equal to zero. The tariff complementarity refers to a decrease in the tariff facing non-member nations due to a decrease in tariffs for members of a preferential trade arrangement. For more information on the complementarity effect, see Saggi (2006), and Mukunoki (2004). Theorem 9 of this paper finds conditions under which this effect may hold for country 2. However, theorem 1 and theorem 3 show that the effect does not hold for country 1 (in fact, the reverse holds). However, as long as these effects have a modest impact on this cross partial derivative, this lemma will still hold.
} 
PROOF: By Lemma 1, $\partial p_{1}\left({ }^{F} t_{1}^{2},{ }^{F} t_{1}^{3}\right) / \partial^{F} t_{1}^{2}<0$ and $\partial p_{1}\left({ }^{F} t_{1}^{2},{ }^{F} t_{1}^{3}\right) / \partial^{F} t_{1}^{3}>0$, at the uniform tariff when a free trade agreement is potentially the equilibrium. By assumption $\partial^{2} p_{1}\left({ }^{F} t_{1}^{2},{ }^{F} t_{1}^{3}\right) / \partial^{F} t_{1}^{2} \partial^{F} t_{1}^{3}=0$ Thus, if ${ }^{F} t_{1}^{3}$ is not constrained to equal ${ }^{F} t_{1}^{2}$, party $F_{1}$ can increase its chances of election by increasing ${ }^{F} t_{1}^{3}$.

Q.E.D.

Theorem 1 shows that a free trade agreement increases $t_{1}^{3}$ which benefits labour and hurts capital. Thus, it might be argued that it is possible for the pro-capital party to support a free trade agreement even though the net benefits to capital (benefits in country 1 minus losses in country 2) are negative. This could be true if the effects on $t_{1}^{3}$ benefit labour enough. However, theorem 2 establishes that a free trade agreement can only be an equilibrium policy for party $F_{1}$, when the net benefits to the capital lobby are higher under an agreement than under a positive $t_{1}^{2}$ :

THEOREM 2: Assume theorem 9 holds. ${ }^{13}$ A necessary condition for a free trade agreement to be an equilibrium policy for party $F_{1}$ is for the net benefits to capital to be higher when $t_{1}^{2}=t_{2}^{1}=0$ (as would be true with an agreement) than when $t_{1}^{2}>0$ and $t_{2}^{1}>0$.

PROOF: For simplicity it is assumed that either $p_{2}=1$ or $p_{2}=0$. (Since expected returns are additively separable in the tariff vectors of the different parties in country 1 , there is no loss of generality in this assumption).

Assume that it is not the case that the net benefits to capital must be positive for party $F_{1}$ to support a free trade agreement. Let $\left(0,{ }^{F} t, 0\right)$ be the $\left({ }^{F} t_{1}^{2},{ }^{F} t_{1}^{3}, t_{2}^{1}\right)$ set which party $F_{1}$ offers when it supports a free trade agreement combined with the level of $t_{2}^{1}$ country 2 imposes. The Stolper-Samuelson theorem guarantees that the labour lobby will prefer any positive ${ }^{F} t_{1}^{2}$ and $t_{2}^{1}$ to a free trade agreement (for a given $\left.{ }^{F} t_{1}^{3}\right)$. Ergo, $\left({ }^{F} t,{ }^{F} t, t\right)$ will be preferred by both lobby groups and hence would increase $F_{1}$ 's chance of election.

Q.E.D.

Note that theorem 2 is due to the capital lobby's concern not being limited to its

\footnotetext{
${ }^{12}$ This may seem to contradict Article XXIV of GATT, which only allows free trade agreements when post agreement trade restrictions are no higher than they were before free trade. Thus, it must be either implicitly assumed that this restriction is not binding or the theorem must be reinterpreted as saying tariffs will be no lower after free trade.

${ }^{13}$ If theorem 9 (see section 3.C) holds, the effect of free trade on $t_{2}^{3}$ will tend to benefit the capital lobby and hurt the labour lobby in country 1 . Since these effects would reinforce the results of the theorem, changes in $t_{2}^{3}$ may be ignored in this theorem.
} 
capital holdings in country 1 . It also considers the lower return to its holdings in country 2 due to a free trade agreement. Since theorem 2 establishes that the net benefits to capital must be higher under a free trade agreement for it to be an equilibrium strategy, joint ownership of capital means that party $F_{1}$ is less likely to support an agreement than when capital is not owned jointly. As the same logic applies to party $P_{1}$, we can conclude that joint ownership reduces the probability that country 1 will support a free trade agreement.

\section{B. Pro-labour Party in Country 1}

This section briefly discusses the conditions under which party $P_{1}$ will propose a free trade agreement with country 2 . It also discusses the effect an agreement has on the value of $t_{1}^{3}$ party $P_{1}$ chooses. As in section 3.A, it is assumed that $p_{2}$ is either equal to zero or one. Using notation of the type established in section 3.A, party $P_{1}$ 's optimization problem is

$$
\min _{P^{P} t_{1}^{2}, P_{1}^{3}} p_{1}\left({ }^{P} t_{1}^{2},{ }^{P} t_{1}^{3}\right)
$$

such that ${ }^{P} t_{1}^{2}={ }^{P} t_{1}^{3}={ }^{P} t_{1}^{U}$

When no free trade agreement is proposed, its first order condition is

$$
\frac{\partial p_{1}\left({ }^{P} t_{1}^{2},{ }^{P} t_{1}^{3}\right)}{\partial^{P} t_{1}^{2}}+\frac{\partial p_{1}\left({ }^{P} t_{1}^{2},{ }^{P} t_{1}^{3}\right)}{\partial^{P} t_{1}^{3}}=0
$$

This first order condition is of the same general form as the equivalent one for party $F_{1}$ (equation [29]).

Sufficient conditions for a minimum include $\partial^{2} p_{1}\left({ }^{P} t_{1}^{2},{ }^{P} t_{1}^{3}\right) / \partial\left({ }^{P} t_{1}^{2}\right)^{2}>0$, $\partial^{2} p_{1}\left({ }^{P} t_{1}^{2},{ }^{P} t_{1}^{3}\right) / \partial\left({ }^{P} t_{1}^{3}\right)^{2}>0$, and $\partial^{2} p_{1}\left({ }^{P} t_{1}^{2},{ }^{P} t_{1}^{3}\right) / \partial^{P} t_{1}^{2} \partial^{P} t_{1}^{3} \geq 0$. This section assumes that $\partial^{2} p_{1}\left({ }^{P} t_{1}^{2}, t_{1}^{P}\right) / \partial^{P} t_{1}^{2} \partial^{P} t_{1}^{3}=0$.

Lemma 2 establishes a necessary condition for a free trade agreement to be party $P_{1}$ 's preferred alternative:

LEMMA 2: Suppose $P_{1}$ acts as a Cournot competitor. Further, assume that all optimal tariffs are nonnegative and that $\partial^{2} p_{1}\left({ }^{P} t_{1}^{2},{ }^{P} t_{1}^{3}\right) / \partial^{P} t_{1}^{2} \partial^{P} t_{1}^{3}=0$. In addition, it is assumed that $p_{1}\left({ }^{P} t_{1}^{2},{ }^{P} t_{1}^{3}\right)$ has unique minimum values of ${ }^{P} t_{1}^{2}$ and ${ }^{P} t_{1}^{3}$ (is strictly convex), given the proposed tariffs of party $F_{1}$. A necessary condition for a free trade agreement to be an equilibrium is for $\partial p_{1}\left({ }^{P} t_{1}^{2},{ }^{P} t_{1}^{3}\right) / \partial^{P} t_{1}^{2}>0$ and $\partial p_{1}\left({ }^{P} t_{1}^{2},{ }^{P} t_{1}^{3}\right) / \partial^{P} t_{1}^{3}<0$ at the solution to problem (32). 
PROOF: The proof of lemma 2 follows the same logic as that of lemma 1 . Thus, it is not presented here.

Q.E.D.

Theorem 3 shows that a free trade agreement raises country 1's tariff with country 3 when party $P_{1}$ is in power:

THEOREM 3: Given the assumptions of lemma 2, with a free trade agreement between countries 1 and $2,{ }^{P} t_{1}^{3}$ is higher than it would be without an agreement.

PROOF: By lemma 2, $\partial p_{1}\left({ }^{P} t_{1}^{2},{ }^{P} t_{1}^{3}\right) / \partial^{P} t_{1}^{2}>0$ and $\partial p_{1}\left({ }^{P} t_{1}^{2},{ }^{P} t_{1}^{3}\right) / \partial^{P} t_{1}^{3}<0$, at the uniform tariff when a free trade agreement is potentially the equilibrium. By assumption, $\partial^{2} p_{1}\left({ }^{P} t_{1}^{2},{ }^{P} t_{1}^{3}\right) / \partial^{P} t_{1}^{2} \partial^{P} t_{1}^{3}=0$. Thus, if ${ }^{P} t_{1}^{3}$ is not constrained to be equal to ${ }^{P} t_{1}^{2}$, party $P_{1}$ can increase its chances of election by increasing ${ }^{P} t_{1}^{3}$.

Q.E.D.

Together, theorem 1 and 3 show that country 1's tariff with country 3 will be higher when it enters into a free trade agreement.

Theorem 4 establishes that for a free trade agreement to be an equilibrium policy for party $P_{1}$, the net benefits to the capital lobby must be higher for $t_{1}^{2}=0$ than any $t_{1}^{2}>0$ :

THEOREM 4: Assume theorem 9 holds. A necessary condition for a free trade agreement to be an equilibrium policy for party $P_{1}$ is for the net benefits to capital to be higher when $t_{1}^{2}=t_{2}^{1}=0$ (as would be true with a free trade agreement) than any positive $t_{1}^{2}$ and $t_{2}^{1}$

PROOF: The proof follows exactly the same logic as that of theorem 2.

Q.E.D.

Together theorems 2 and 4 establish that a necessary condition for country 1 to be willing to adopt a free trade agreement is for the net benefits to the capital lobby to be higher under free trade than under any positive tariff. This is a stronger condition than would be required if the capital lobby in country 1 only held capital in country 1 . In this case, it would only be required that the benefits to capital in country 1 be higher under a free trade agreement than under any positive tariff.

Theorem 5 shows that if certain conditions are met, $P_{1}$ only supports a free trade agreement when party $F_{1}$ supports free trade:

THEOREM 5: Assume that theorem 4 holds. Further assume that the option of $t_{2}^{1}<0$ is ruled out. A necessary condition for proposing a free trade agreement to be an equilibrium strategy for party $P_{1}$ is for an agreement to be an equilibrium strategy for party $F_{1}$.

PROOF: Assume not. By definition, party $F_{1}$ is the party with a platform most 
favourable to capital. Thus, if it is not offering a free trade agreement but party $P_{1}$ is, the net benefits to capital must be higher under a positive $t_{2}^{1}$ than under $t_{2}^{1}=t_{1}^{2}=0$. However, theorem 4 states that a necessary condition for party $P_{1}$ to offer a free trade agreement is for the net benefits to capital to be higher when $t_{2}^{1}=t_{1}^{2}=0$ than any positive $t_{2}^{1}$ and $t_{1}^{2}$. A contradiction.

Q.E.D.

It should be noted that theorem 5 can be interpreted as showing that a sufficient condition for party $F_{1}$ to support free trade is for party $P_{1}$ to be in favour of free trade.

Theorem 6 shows that when both political parties in country 1 support a free trade agreement, it is likely that ${ }^{P h} t_{1}^{3}>{ }^{F h} t_{1}^{3}$ :

THEOREM 6: When parties $F_{1}$ and $P_{1}$ both propose a free trade agreement, the labour lobby will only make campaign contributions when ${ }^{P h} t_{1}^{3}>{ }^{F h} t_{1}^{3}$.

PROOF: Reconsider the first order condition for the labour lobby in country 1 :

$$
\frac{\partial p_{1}\left(c_{1}^{K}, c_{1}^{L}\right)}{\partial c_{1}^{L}} L_{1} \Delta w_{1}=1
$$

Clearly this first order condition only holds with equality when $\Delta w_{1}<0$. When both parties propose a free trade agreement, ${ }^{F h} t_{1}^{2}={ }^{P h} t_{1}^{2}$. Accordingly, $\Delta \mathrm{w}_{1}$ can only be negative if ${ }^{P h} t_{1}^{3}>{ }^{F h} t_{1}^{3}$.

Q.E.D.

\section{The Political Parties in Country 2}

Theorem 7 shows that the net benefits to the capital lobby being positive are a sufficient condition for a free trade agreement to be an equilibrium strategy for both parties in country 2 :

THEOREM 7: Assume that theorems 1 and 3 hold but GATT restrictions prevent $t_{1}^{3}$ from rising after a free trade agreement. A sufficient condition for a free trade strategy to dominate any positive proposed $t_{2}^{1}$ for both parties in country 2 is for the net benefits to capital under free trade to be greater than the net benefits under any positive $t_{2}^{1}$ and $t_{1}^{2}$.

PROOF: Assume the theorem does not hold. Then there must be some positive policy vector $\left(\begin{array}{c}h-1 \\ t\end{array} 2, h_{2}-3, t_{1}-2\right)$ (where ${ }^{h-1} t_{2}>0$ and $\left.{ }^{h-2} t_{1}>0\right)$ which gives party $h(h=$ $F, P)$ a better chance of election. However, by assumption, the capital party prefers $\left(0,{ }^{h-3} t_{2}, 0\right)$ Moreover, the Stolper-Samuelson theorem guarantees that the labour lobby will prefer this policy vector. Ergo, $\left(\begin{array}{l}h-1 \\ t_{2}, h_{2}\end{array} t_{2}, t_{1} t_{1}\right)$ cannot be an equilibrium 
and the theorem is established.

Q.E.D.

Note that the sufficient conditions for both political parties in country 2 to propose a free trade agreement are the necessary conditions for either party in country 1 to propose a free trade agreement. Therefore, it is never the case that country 1 will propose a free trade agreement but country 2 rejects the offer. Moreover, theorem 5 says that when party $P_{1}$ supports a free trade agreement, party $F_{1}$ is also in favour. Combined with these results it can be concluded that whenever party $P_{1}$ supports a free trade agreement, it is the outcome of the political process.

Theorem 8 shows that if certain conditions are met, it cannot be the case that in equilibrium party $F_{2}$ will support a free trade agreement but party $P_{2}$ will not propose an agreement:

THEOREM 8: A sufficient condition for proposing a free trade agreement to be an equilibrium strategy for party $P_{2}$ is for a free trade agreement to be an equilibrium strategy for party $F_{2}$.

PROOF: Assume this theorem does not hold and that party $F_{2}$ offers a free trade agreement when party $P_{2}$ does not. Party $P_{2}$ must be offering some positive policy vector $\left({ }^{P} t_{2}, P_{t}-3, P_{1} t_{1}\right)$ (where ${ }^{P}-12>0$ and $\left.{ }^{P} t_{1} \geq 0\right)$ which gives $P_{2}$ a better chance of winning. Note that $F_{2}$ is defined as the party most favourable to capital. Hence, capital must prefer the policy vector $\left(0,{ }^{F} t_{2}^{-3}, 0\right)$ being offered by $F_{2}$. In addition, the Stolper-Samuelson theorem insures that labour would prefer $t_{2}^{1}=t_{1}^{2}=0$ to any $t_{2}^{1}>0$ and $t_{1}^{2}>0$. Thus, by offering a free trade agreement, party $P_{2}$ could both increase the support of labour and reduce the opposition of capital.

Q.E.D.

Besides being a sufficient condition for party $P_{2}$ to support free trade, the above theorem could be restated as a necessary condition for party $F_{2}$ supporting a free trade agreement being party $P_{2}$ 's support of an agreement.

Theorem 9 examines the effect a free trade agreement might have on country 2 's tariff with country 3 . Most free trade agreements include some sort of rules of origin requirements to prevent external countries from circumventing the tariff rate of the country with the highest external tariff by transhipping through the country with the lower tariff. However, the application of such rules is often complex. Indeed, in the case of NAFTA, this has lead to disputes and further negotiations involving the rules of origin requirements. Theorem 9 assumes that these rules are imperfect at preventing transhipment:

THEOREM 9: Assume that the assumptions of theorem 1 hold. Further, assume 
that $\partial^{2} w_{2}\left(\mathbf{t}^{\mathbf{F P}}\right) / \partial t_{2}^{3} \partial t_{2}^{1}=\partial^{2} w_{2}\left(\mathbf{t}^{\mathbf{F P}}\right) / \partial t_{2}^{3} \partial t_{1}^{2}=\partial^{2} p / \partial c_{2}^{K} \partial c_{2}^{L}=0$. If, before a free trade agreement, $t_{1}^{3} \geq t_{2}^{3}=0$, then the agreement $t_{2}^{3}$ will be lower when rules of origin requirements cannot be perfectly enforced.

PROOF: First, consider the case where party $F_{2}$ is elected in country 2 . Let $N B^{g h}\left(t^{g h}\right)$ be the benefits to capital when party $g_{1}$ is elected in country 1 and party $h_{2}$ is elected in country 2 . Thus, the probability of party $F_{2}$ 's election is written as

$$
p_{2}\left(c_{2}^{K}\left(N B^{g F}\left(\mathbf{t}^{\mathbf{g F}}\right)-N B^{g P}\left(\mathbf{t}^{\mathbf{g P}}\right)\right), c_{2}^{L}\left(w_{2}^{g F}\left(\mathbf{t}^{\mathbf{g F}}\right)-w_{2}^{g P}\left(\mathbf{t}^{\mathbf{g P}}\right)\right)\right)
$$

However, note that we can write $N B^{g F}\left(\mathbf{t}^{\mathbf{g F}}\right)=b_{1}^{g F}\left(\mathbf{t}^{\mathbf{g F}}\right)+b_{2}^{g F}\left(\mathbf{t}^{\mathbf{g F}}\right)$, where $b_{1}^{g F}$ represents the benefits capital receives from its holdings in country 1 and $b_{1}^{g F}$ is the benefit capital receives from its holdings in country 2 due to $\mathbf{t}^{\mathbf{g F}}$ being implemented. $b_{1}^{g P}$ and $b_{2}^{g P}$ are similarly defined. ${ }^{14}$ This allows the optimal level of ${ }^{g F} t_{2}^{3} \in \mathbf{t}_{0}^{\mathbf{g F}}$ to be defined below:

$$
{ }^{g F} t_{2}^{3}=\operatorname{argmax}\left\{p_{2}\left(c_{2}^{K}\left(b_{1}^{g F}\left(\mathbf{t}^{\mathrm{gF}}\right)+b_{2}^{g F}\left(\mathbf{t}^{\mathrm{gF}}\right)-b_{1}^{g P}\left(\mathbf{t}^{\mathbf{g}^{P}}\right)-b_{2}^{g P}\left(\mathbf{t}^{\mathrm{g}^{P}}\right)\right), c_{2}^{L}\left(w_{2}^{g F}\left(\mathbf{t}^{\mathrm{gF}}\right)-w_{2}^{g P}\left(\mathbf{t}^{\mathrm{gP}}\right)\right)\right)\right\}
$$

where ${ }^{g F} t_{2}^{3} \in \mathbf{t}_{0}^{\mathbf{g F}}$

${ }^{g F} t_{2}^{3}$ is implicitly defined by equation (35):

$$
\frac{\partial p_{2}}{\partial c_{2}^{K}}\left[\frac{\partial c_{2}^{K}}{\partial b_{1}^{g F}} \frac{\partial b_{1}^{g F}}{\partial^{g F} t_{2}^{3}}+\frac{\partial c_{2}^{K}}{\partial b_{2}^{g F}} \frac{\partial b_{2}^{g F}}{\partial^{g F} t_{2}^{3}}\right]=-\frac{\partial p_{2}}{\partial c_{2}^{L}} \frac{\partial c_{2}^{L}}{\partial w_{2}^{g F}} \frac{\partial w_{2}^{g F}}{\partial^{g F} t_{2}^{3}}
$$

Before a free trade agreement there is no incentive for trade between country 1 and 3 to go through country 2 (because $t_{1}^{2}=t_{1}^{3}$ ). Thus, we may assume that $\partial b_{1}^{g F}\left(\mathbf{t}^{\mathbf{g F}}\right) / \partial_{1}^{g F} t_{2}^{3}=0 .{ }^{15}$ This allows equation (35) to be rewritten as follows:

$$
\frac{\partial p_{2}}{\partial c_{2}^{K}} \frac{\partial c_{2}^{K}}{\partial b_{2}^{g F}} \frac{\partial b_{2}^{g F}}{\partial^{g F} t_{2}^{3}}=-\frac{\partial p_{2}}{\partial c_{2}^{L}} \frac{\partial c_{2}^{L}}{\partial w_{2}^{g F}} \frac{\partial w_{2}^{g F}}{\partial^{g F} t_{2}^{3}}
$$

After a free trade agreement, the situation is quite different. Since we have assumed that $t_{1}^{3} \geq t_{2}^{3}$ before the agreement, it is clear from theorem 1 that $t_{1}^{3}>t_{2}^{3}$.

\footnotetext{
${ }^{14}$ Specifically, $b_{1}^{g F}\left(\mathbf{t}^{\mathrm{gF}}\right)-b_{1}^{g P}\left(\mathbf{t}^{\mathrm{gP}}\right)=K_{1} \Delta r_{1}^{2}$ and $b_{2}^{g F}\left(\mathbf{t}^{\mathrm{gF}}\right)-b_{2}^{g P}\left(\mathbf{t}^{\mathrm{gP}}\right)=K_{2} \Delta r_{2}^{2}$ (see section 2.B).

${ }^{15}$ It is possible that increased economic activity from a lowering of tariffs between country 2 and 3 will expand the size of the market in country 2 for the products of country 1 . Such indirect effects are ignored in this section.
} 
Therefore, if rules of origin requirements are not fully effective, it follows that some trade between country 1 and 3 will go through country 2 . Thus, using the Stolper-Samuelson theorem it follows that $\partial r_{1}^{F P}\left(\mathbf{t}^{\mathbf{F P}}\right) / \partial t_{2}^{3}<0$. Consequently, using equations (35) and (36) it is clear that the marginal political cost of an increase in $t_{2}^{3}$ is higher than it was before the free trade agreement. By the assumptions of the theorem, the marginal benefit is unchanged. Consequently, a lower proposed value of $t_{2}^{3}$ is predicted.

The same basic logic applies when country 2 elects party $P_{2}$.

Q.E.D.

Clearly, the capital lobby has an advantage over the two labour lobbies in influencing trade policy between the members of the free trade agreement and the rest of the world. This is because the capital lobby can internalize the externality to its return in one country from lobbying in the other country. One would expect that as free trade agreements become more common, labour lobbies in the member countries will find ways to better coordinate their lobbying efforts (perhaps by finding ways to make side payments which internalize the externalities their lobbying efforts have on each other). ${ }^{16}$

Also, it should be noted that sufficient conditions for country 2 to be willing to negotiate a free trade agreement with country 1 are precisely the necessary conditions for country 1 to be willing to negotiate a free trade agreement with country 2 . Thus, they are a necessary condition for a free trade agreement to be negotiated between countries 1 and 2 .

It is difficult to say if labour in country 2 is in a better or worse position when the same lobby represents capital in both countries. If the net benefits to capital from an agreement are positive, it is assured that whichever party is elected in country 2 it will support a free trade agreement. However, if this condition is not met, it is assured that country 1 will not support free trade.

Theorem 10 shows that when both $F_{2}$ and $P_{2}$ propose a free trade agreement, it is likely that party $P_{2}$ will propose a higher $t_{2}^{3}$ than $F_{2}$ :

THEOREM 10: When parties $F_{2}$ and $P_{2}$ both propose a free trade agreement, the labour lobby will only make campaign contributions when ${ }^{g P} t_{1}^{3}>{ }^{g F} t_{1}^{3}$.

PROOF: The proof is analogous to that of theorem 6 and hence is not repeated here.

Q.E.D.

\footnotetext{
${ }^{16}$ Perhaps the net transfers out of Canadian locals of international unions are an example of this type of side payment. However, if this is the case, it is surprising that in recent years as trade agreements have become more common, Canadian unions have broken away from their international parents
} 


\section{Effects of Common Ownership of Capital on Tariffs with Country 3}

This paper has assumed that the same lobby group owns capital in both countries considering a free trade agreement. This section examines the implications of this for tariffs with the rest of the world when a free trade agreement is in place. It assumes that neither country's trade with the rest of the world affects the international price vector. Theorem 11 shows that external tariffs in at least one country are lower when the same lobby group represents capital in both countries:

THEOREM 11: Let the international price vector be taken as given and let a free trade agreement be in place. Assume that rules of origin requirements cannot be perfectly enforced. Additionally assume that $\partial^{2} p_{j}\left(c_{j}^{K}, c_{j}^{L}\right) / \partial c_{j}^{K} \partial c_{j}^{L}=\partial^{2} p_{j}\left({ }^{g h} t_{j}{ }_{j},{ }^{g h} t_{j}^{3}\right) /$ $\partial^{g h} t_{j}^{i} \partial^{g h} t_{j}^{3}=0$ for $j=1,2, i=1,2$ and $j \neq i$. When capital in both countries is owned by the same individuals, and represented by a common lobby, tariffs with the rest of the world are lower in at least one country than when capital is not owned jointly.

PROOF: Assume country $i$ 's election has already taken place. Let $\mathbf{t}^{\mathbf{F}}\left(\mathbf{t}^{\mathbf{P}}\right)$ be the tariff vector $\left(t_{1}^{2}, t_{1}^{3}, t_{2}^{1}, t_{2}^{3}\right)$ resulting from party $F_{\mathrm{j}}\left(P_{j}\right)$ being elected in country $j$. Somewhat similar to theorem 9 , let $b_{k}^{F}\left(\mathbf{t}^{\mathbf{F}}\right)$ (alternatively, $b_{k}^{P}\left(\mathbf{t}^{\mathbf{P}}\right)$ ) be the corresponding benefits to capital in country $k(k=1,2)$ from party $F_{j}\left(P_{j}\right)$ being elected in country $j$. The probability of party $F_{j}$ being elected in country $j=1,2$ is

$$
p_{j}\left(c _ { j } ^ { K } \left(b_{1}^{g F}\left(\mathbf{t}^{\mathbf{g}^{\mathrm{F}}}\right)+b_{2}^{g F}\left(\mathbf{t}^{\mathrm{gF}}\right)-\left(b_{1}^{g P}\left(\mathbf{t}^{\mathrm{gP}}\right)-b_{2}^{g P}\left(\mathbf{t}^{\mathrm{gP}}\right)\right), c_{j}^{L}\left(w_{j}^{g F}\left(\mathbf{t}^{\mathrm{gF}}\right)-w_{j}^{g P}\left(\mathbf{t}^{\mathrm{gP}}\right)\right) \text { for } j=1,2 \wedge g=F, P .\right.\right.
$$

Maximizing the above with respect to ${ }^{h} t_{j}^{3}(h=F, P)$ :

$$
\frac{\partial p_{j}}{\partial c_{j}^{K}}\left[\frac{\partial c_{j}^{K}}{\partial b_{i}^{h}} \frac{\partial b_{i}^{g h}}{\partial^{g h} t_{j}^{3}}+\frac{\partial c_{j}^{K}}{\partial b_{j}^{g h}} \frac{\partial b_{j}^{g h}}{\partial^{g h} t_{j}^{3}}\right]=-\frac{\partial p_{j}}{\partial c_{j}^{L}} \frac{\partial c_{j}^{L}}{\partial w_{j}^{g h}} \frac{\partial w_{j}^{g h}}{\partial^{g h} t_{j}^{3}}, \quad h=F, P
$$

If tariffs before the free trade agreement are lower in country $j$ than in country $i$, both terms in square brackets are negative, if there is common ownership of capital. Otherwise, the first term will be zero (as would be true if ownership of capital is limited to residents of the country in question). Consequently, when the same lobby group owns capital in both countries, tariffs in at least one country are lower than is the case when there is no cross country ownership of capital.

Q.E.D. 


\section{Conclusion}

This paper has attempted to contribute to the expansion of the endogenous trade policy literature to the formation of free trade agreements. One of its more important contributions has been to establish some necessary and sufficient conditions for free trade to be politically feasible. It has also examined the effect a free trade agreement has on the external tariffs of member countries. Furthermore, the implications of common ownership of capital were examined. To accomplish these goals, the paper has used the rules of GATT to assume away the bargaining problem involved when countries enter into international agreements. It did this on the premise that the model was already quite complex and adding a bargaining framework would further complicate matters and therefore distract from the main features of the model. However, the long negotiations involved in establishing real world trade agreements imply that GATT regulations do not completely eliminate the bargaining problem. Moreover, even if GATT regulations were fully binding they would not eliminate a bargaining problem for customs unions where the level of a common external tariff must be decided on. Therefore, a useful area for further research would be to incorporate an international bargaining framework into a public choice model.

One possible criticism of this model is that the order of countries in terms of capital intensities is ad hoc. However little would be added by changing the ordering. For example, making country 3 the most capital intensive but retaining the ordering of countries 1 and 2 should not have any real effect. It would merely make country 2 the country that had to have a common tariff with the rest of the world. A more realistic case would be one where the rest of the world consisted of countries that were both more and less capital intensive than countries 1 and 2 . However, this would complicate the model and is unlikely to result in significantly different results. Nevertheless, this conjecture should be confirmed by further research.

\section{Acknowledgements}

This paper benefited significantly from the comments and suggestions of Sam Bucovetsky and two anonymous referees. 


\section{References}

Austen-Smith, David. (1991) Rational consumers and irrational voters: A review essay on Black hole tariffs and endogenous policy theory, by Stephen Magee, William Brock and Leslie Young, Cambridge University Press 1989. Economics and Politics, 3(1), 73-92.

Bagwell, Kyle and Robert W. Staiger. (1999) An economic theory of GATT. American Economic Review, 89(1), 215-248.

Balistreri, Edward J. (1995) Preference revelation and the endogenous trade policy model: Empirical and experimental evidence for Stolper-Samuelson welfare effects. Ph.D. dissertation, University of Colorado.

Balistreri, Edward J. (1997) The performance of the Heckscher-Ohlin-Vanek model in predicting endogenous policy forces at the individual level. Canadian Journal of Economics, 30(1), 1-17.

Beaulieu, Eugene. (2002) Factor or industry cleavages in trade policy?: An empirical analysis of the Stolper-Samuelson theorem. Economics and Politics, 14(2), 99-131.

Beaulieu, Eugene and Christopher Magee. (2002) Four simple tests of campaign contributions and trade preferences. Economics and Politics, 16(2), 163-187.

Dutt, Pushan, and Devashish Mitra. (2002) Endogenous trade policy through majority voting: An Empirical Investigation. Journal of International Economics, 58, 107-133.

Eurostat. (2007): European Union foreign direct investment yearbook 2007. Luxembourg: Statistical Office of the European Communities.

Feenstra, Robert C. and Tracy R. Lewis. (1991) Negotiated trade restrictions with private political pressure. Quarterly Journal of Economics, 106(4), 1287-1307.

General Agreement on Tariffs and Trade (GATT). (1986) General agreement on tariffs and trade: Text of the general agreement. Geneva.

Grossman, Gene M. and Elhanan Helpman. (1995) The politics of free-trade agreements. American Economic Review, 85(4), 667-690.

Grossman, Gene M. and Elhanan Helpman. (1996) Foreign investment with endogenous protection. In The political economy of trade policy: Papers in honor of Jagdish Bhagwati, ed. Robert C. Feenstra, Gene M. Grossman and Douglas A. Irwin. Cambridge: The MIT Press.

Hillman, Arye L. (1982) Declining industries and political-support protectionist motives. American Economic Review, 72(5), 1180-7.

Hillman, Arye L. and Heinrich W. Ursprung. (1993) Multinational firms, political competition, and international trade policy. International Economic Review, 34(2), 347-63.

Kim, Gi-Hong. (2000) The Role of GATT in trade negotiations: A game-theoretic perspective. International Economic Journal, 14(4), 103-123.

Kroll, John A. (1996) Trading blocs and multilateralism: Complementary or contradictory trade policies? in Economic Integration in the Americas ed. Christos C. Paraskevopoulos, and Ricardo Grinspun. Cheltenham: Edward Elgar.

Leidy, Michael P. (1994) Trade policy and indirect rent seeking: A synthesis of recent work. 
Economics and Politics, 6(2), 97-118.

Levy, Philip I. (1997) A political-economic analysis of free-trade agreements. American Economic Review, 87(4), 506-519.

Ludema, Rodney D. (1991) International trade bargaining and the most favored-nation clause. Economics and Politics, 3(1), 1-20.

Magee, Stephen P. (1980) Three simple tests of the Stolper-Samuelson theorem. In Issues in international economics, ed. Peter Oppenheimer. Stocksfield: Oriel Press.

Magee, Stephen P., William A. Brock, and Leslie Young. (1989) Black hole tariffs and endogenous policy theory: Political economy in general equilibrium. Cambridge: Cambridge University Press.

Magee, Stephen P., and Hak-Loh Lee. (2001) Endogenous tariff creation and tariff diversion in a customs union. European Economic Review, 45, 495-518.

Mayer, Wolfgang. (1984) Endogenous tariff formation. American Economic Review, 74(5), 970-985.

Mayer, Wolfgang. (1993) Lobbying for tariff policies. Review of International Economics, 1(3), 221-233.

Milner, Helen V. and B. Peter Rosendorff. (1996) Trade negotiations, information and domestic politics: The role of domestic groups. Economics and Politics, 8(2), 145-189.

Mukunoki, Hiroshi. 2004. On the optimal external tariff of a free trade area with internal market integration. Japan and the World Economy, 16(4), 231-248.

Ornelas, Emanuel. (2005) Rent destruction and the political viability of free trade agreements. Quarterly Journal of Economics, 120(4), 1476-1506.

Panagariya, Arvind and Ronald Findlay. (1996) A political-economy analysis of free-trade areas and customs unions. In The political economy of trade policy: Papers in honor of Jagdish Bhagwati, ed. Robert C. Freenstra, Gene M. Grossman and Douglas A. Irwin. Cambridge: The MIT Press.

Pyne, Derek. (2000) Revealed preference tests of the Stolper-Samuelson Theorem. The International Trade Journal, 24(4), 355-375.

Pyne, Derek. (2006) Microfoundations of influencing public opinion: Lobbying and voting for trade policies. Journal of Economic Integration, 21(3), 551-576.

Richardson, Martin. (1993) Endogenous protection and trade diversion. Journal of International Economics, 34, 309-24.

Richardson, Martin. (1994) Why a free trade area?: The tariff also rises. Economics and Politics, 6(1), 79-96.

Saggi, Kamal. (2006) Preferential trade agreements and multilateral tariff cooperation. International Economic Review, 47(1), 29-57.

Statistics Canada. (2007) Foreign direct investment, 2006. The Daily. May 9. Ottawa: Statistics Canada.

Statistics New Zealand (2007) Balance of Payments and International Investment Position: Year ended 31 March 2007. Wellington: Statistics New Zealand.

Stolper, Wolfgang F. and Paul A. Samuelson. (1941) Protection and real wages. Review of Economic Studies, 9, 58-74. 
Yang, C.C. (1995) Endogenous tariff formation under representative democracy: A probabilistic voting model. American Economic Review, 85(4), 956-963.

Young, Leslie and Stephen P. Magee. (1986) Endogenous protection, factor returns and resource allocations. Review of Economic Studies, 53, 407-419. 